\title{
Synthesis and NMR study of pyridinocholaphanes
}

\author{
Pramod S. Pandey,* Roopali Rai and Rhiddi B. Singh \\ Department of Chemistry, Indian Institute of Technology, Hauz Khas, New Delhi 110016, India \\ Received 28 June 2001; revised 16 October 2001; accepted 8 November 2001
}

\begin{abstract}
Pyridinocholaphanes based on cholic, deoxycholic and lithocholic acids with ethylenediamine and m-xylylenediamine as spacers were synthesized using Cs-salt methodology. Their structures were elucidated on the basis of their IR, NMR and FAB mass spectral data. The NMR techniques, DEPT ${ }^{13} \mathrm{C}\left\{{ }^{\prime} \mathrm{H}\right\} 135 / 90$ and HSQC $\left\{{ }^{\prime} \mathrm{H}^{13}{ }^{13} \mathrm{C}\right\}$ were used for the detailed assignment of the carbon atoms of the pyridinocholaphanes.
\end{abstract}

\section{Introduction}

Remarkable progress has been made in the recent past with regard to design and synthesis of chemical models that can imitate the natural processes particularly enzymic reactions. Among these, enzymes possessing $\mathrm{NAD}^{+} / \mathrm{NADH}$ coenzyme have received much attention due to their ability to carry out oxidation-reduction in a highly stereoselective manner. ${ }^{12}$ It has been realized that the dihydronicotinamide moiety attached with macrocyclic systems are better catalysts as they can bind the substrates more effectively. Thus, various systems based on cyclophane, cyclodextrin

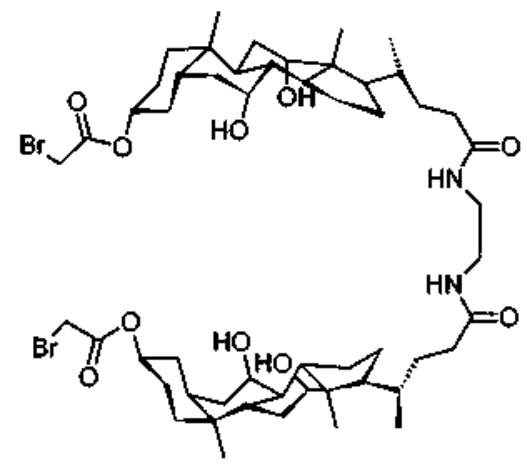<smiles>COC(=O)c1cncc(C(=O)OC(C)(C)O)c1</smiles>

1

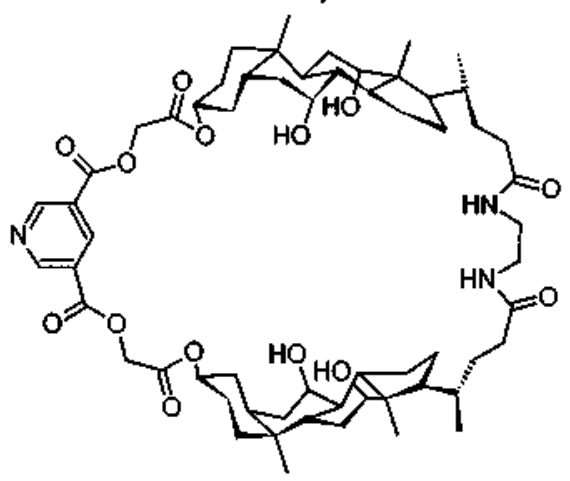

3

Scheme 1. (a) DMF, 12 h, it, $87 \%$.

Keywords: steroid; macrocycles; bis-cesium 3,5-pyridine dicarboxylate; DEPT-NMR; HSQC-NMR. 

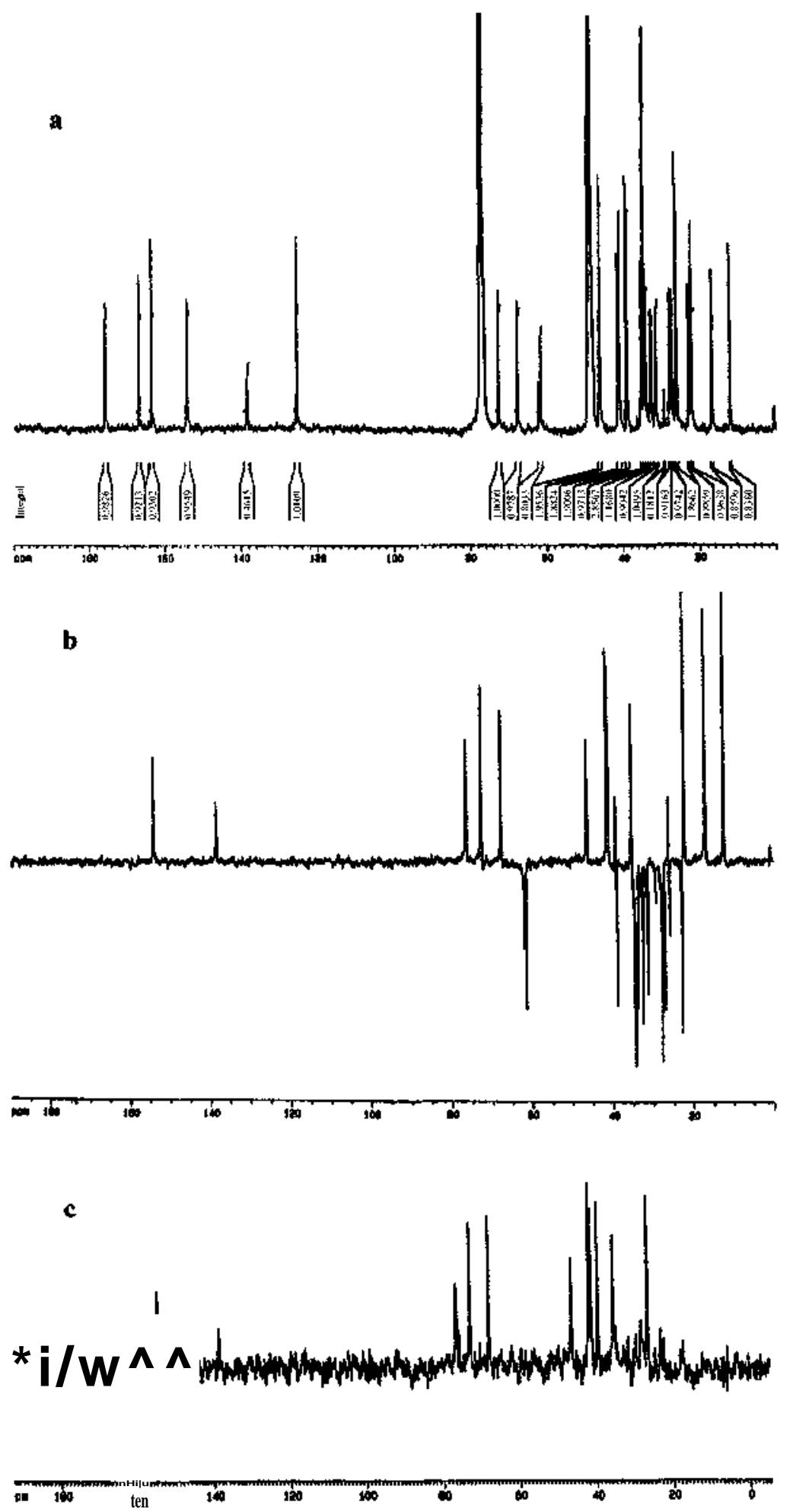

Figure 1. (a) ${ }^{13} \mathrm{C}$ spectrum (b) DEPT $\left.{ }^{13} \mathrm{C}^{1}{ }^{1} \mathrm{H}\right\} 13 \mathrm{~S}-$ and (c) $\mathrm{DEPT}^{\wedge} \mathrm{C}^{\wedge} \mathrm{HjgO}-\mathrm{NMR}$ spectrum of pyridinocholaphane 3.

and crown-ether have been studied. $^{3-5}$ Kellogg and coworkers have designed a large number of macrocyclic dihydronicotinamide systems and have demonstrated that some of the systems give high stereoselectivity in the reduction of activated carbonyl compounds in the presence of $\mathrm{Mg}^{2+}$ ion. $^{6}$

Recently, steroidal macrocyclic systems based on cholic acid have received much attention as they have been found to bind carbohydrate derivatives in enantio- and diastereoselective manner. ${ }^{719}$ As a highly efficient and simple methodology for the construction of cholic acid based receptors, head to head cholaphanes, has been developed by us, ${ }^{10}$ it is considered worthwhile to use this strategy for the design of pyridinocholaphanes as the precursors of $\mathrm{NADH}$ analogues. With the chiral, rigid framework and 


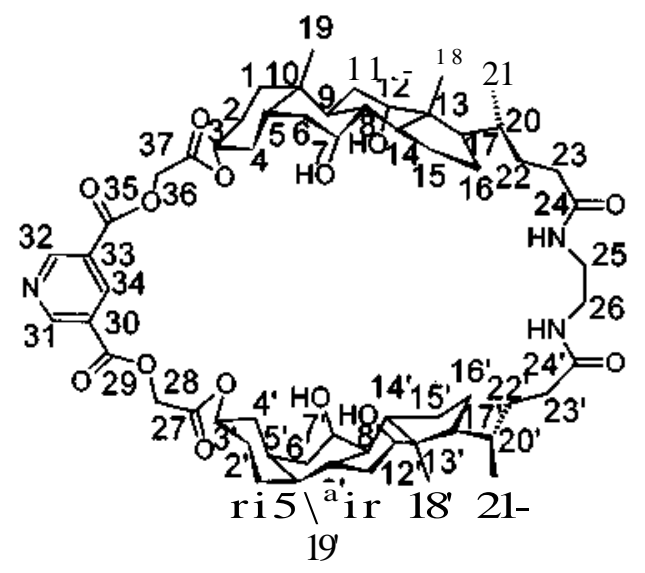

3

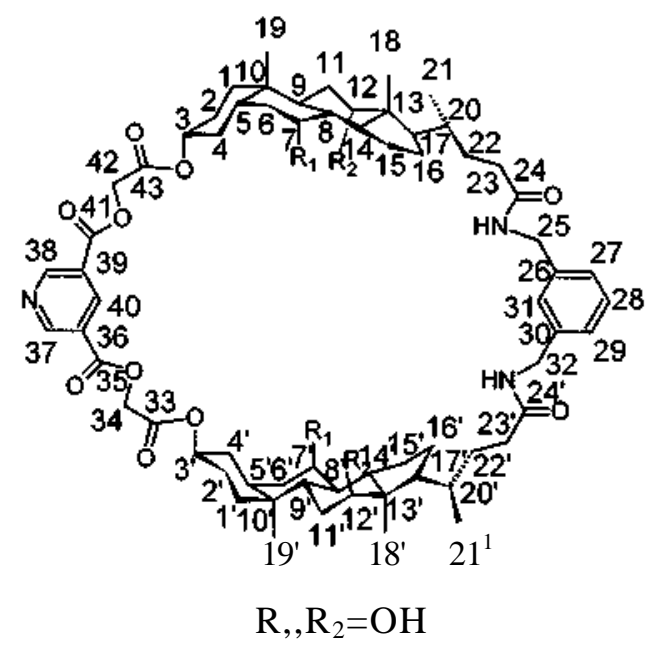

$5 a$

presence of hydroxyl groups in the interior, it is likely that these macrocyclic systems may selectively bind polar substrates and prove to be potential enzyme models for dehydrogenases.

\section{Results and discussion}

Earlier, we have reported the synthesis of head to head cholaphanes using Cs-salt methodology. To see its general applicability, we synthesized various pyridinocholaphanes by incorporating 3,5-pyridine dicarboxylate as a spacer. Their structural identity was established on the basis of ${ }^{1} \mathrm{H},{ }^{13} \mathrm{C}$ NMR and FAB mass spectral analysis.

The precursor bis-bromoacetylcholamide 1, was prepared by the procedure reported earlier. ${ }^{10}$ The cyclization was carried out by treatment of 1 with bis-cesium 3,5-pyridine dicarboxylate 2 in DMF (Scheme 1) to give the pyridinocholaphane 3 in almost quantitative yield. The ${ }^{1} \mathrm{H}$ NMR spectrum of 3 showed a multiplet at 83.27 for amidoethylene protons and a broad singlet at 84.81 for $\mathrm{COCH}_{2}-\mathrm{O}$ protons. The methine protons at 7- and 12positions were observed as broad singlets at 83.75 and 3.88 , respectively, whereas the proton at 3-position
Table 1. ${ }^{13} \mathrm{C}$ NMR spectral data S (ppm) for compounds 3 , 5a-c.

\begin{tabular}{|c|c|c|c|c|}
\hline Carbon & 3 & $5 a$ & $5 b$ & $5 c$ \\
\hline $1,1^{\prime}$ & 34.51 & 34.61 & 34.66 & 34.81 \\
\hline $2,2^{\prime}$ & 27.90 & 28.01 & 28.54 & 28.28 \\
\hline $3,3^{\prime}$ & 76.57 & 76.57 & 76.59 & 76.57 \\
\hline $4,4^{\prime}$ & 34.51 & 34.61 & 32.92 & 31.81 \\
\hline $5,5^{\prime}$ & 40.99 & 41.06 & 41.73 & 41.77 \\
\hline $6,6^{\prime}$ & 31.50 & 29.57 & 29.59 & 26.83 \\
\hline $7,7^{\prime}$ & 67.70 & 67.89 & 26.80 & 26.35 \\
\hline $8,8^{\prime}$ & 39.15 & 39.16 & 34.02 & 35.46 \\
\hline $9,9^{\prime}$ & 26.15 & 26.33 & 35.81 & 40.41 \\
\hline $10,10^{\prime}$ & 34.51 & 34.61 & 33.51 & 34.46 \\
\hline $11,11^{\prime}$ & 26.15 & 26.33 & 25.94 & 20.81 \\
\hline $12,12^{\prime}$ & 72.59 & 72.72 & 72.82 & 40.07 \\
\hline $13,13^{\prime}$ & 46.10 & 46.23 & 46.35 & 42.65 \\
\hline $14,14^{\prime}$ & 41.41 & 41.61 & 46.66 & 56.47 \\
\hline $15,15^{\prime}$ & 22.87 & 23.06 & 23.56 & 24.10 \\
\hline $16,16^{\prime}$ & 27.32 & 27.38 & 27.44 & 30.94 \\
\hline $17,17^{\prime}$ & 46.31 & 46.23 & 48.01 & 55.61 \\
\hline $18,18^{\prime}$ & 12.14 & 12.28 & 12.59 & 12.00 \\
\hline $19,19^{\prime}$ & 22.09 & 22.26 & 22.94 & 23.23 \\
\hline $20,20^{\prime}$ & 35.26 & 35.20 & 35.16 & 34.81 \\
\hline $21,21^{\prime}$ & 16.87 & 17.17 & 17.21 & 18.36 \\
\hline $22,22^{\prime}$ & 32.75 & 31.63 & 31.47 & 31.81 \\
\hline $23,23^{\prime}$ & 34.10 & 32.56 & 31.89 & 29.68 \\
\hline $24,24^{\prime}$ & 175.70 & 174.67 & 174.08 & 173.61 \\
\hline 25 & 39.15 & 43.20 & 43.22 & 43.36 \\
\hline 26 & 39.15 & 138.67 & 138.89 & 138.90 \\
\hline 27 & 163.47 & 126.78 & 126.68 & 126.81 \\
\hline 28 & 61.62 & 126.78 & 126.68 & 126.81 \\
\hline 29 & 166.80 & 126.78 & 126.68 & 126.81 \\
\hline 30 & 125.39 & 138.67 & 138.80 & 138.90 \\
\hline 31 & 154.15 & 128.65 & 128.78 & 128.96 \\
\hline 32 & 154.15 & 43.20 & 43.22 & 43.36 \\
\hline 33 & 125.39 & 163.64 & 163.70 & 163.75 \\
\hline 34 & 138.59 & 61.81 & 61.79 & 62.21 \\
\hline 35 & 166.80 & 166.86 & 166.74 & 166.70 \\
\hline 36 & 61.62 & 125.45 & 125.36 & 125.31 \\
\hline 37 & 163.47 & 154.38 & 154.54 & 154.75 \\
\hline 38 & & 154.38 & 154.54 & 154.75 \\
\hline 39 & & 125.45 & 125.36 & 125.31 \\
\hline 40 & & 138.67 & 138.80 & 138.90 \\
\hline 41 & & 166.86 & 166.74 & 166.70 \\
\hline 42 & & 61.81 & 61.79 & 62.21 \\
\hline 43 & & 163.64 & 163.70 & 163.75 \\
\hline
\end{tabular}

appeared at 84.61 as a multiplet. The characteristic methyl protons at 18,19 and 21 positions appeared at 0.60 (singlet), 0.84 (singlet), and 0.92 (broad singlet), respectively. The remaining steroidal protons showed a complex pattern of signals between 0.99 and $2.50 \mathrm{ppm}$. The presence of pyridine protons at 8.85 and $9.34 \mathrm{ppm}$ and protons for $\mathrm{COCH}_{2}-\mathrm{O}$ - at 84.81 indicated the formation of 3 . The FAB mass spectrum revealed the molecular ion peak at $m l z 1089\left(\mathrm{MH}^{+}\right)$. The structure of pyridinocholaphane 3 was further confirmed by its quantitative ${ }^{13} \mathrm{C}$ NMR spectrum (Fig. la). The detailed assignments of ${ }^{13} \mathrm{C}$ NMR signals were made on the basis of $\left.\operatorname{DEPT}^{\wedge} \mathrm{C}^{\wedge} \mathrm{H}\right\} 135 / 90$ - and $\mathrm{HSQC}^{\wedge} \mathrm{H}-{ }^{\wedge} \mathrm{CJ}-\mathrm{NMR}$ studies and given in Table 1.

The carbonyl carbon, C-24 of cholic acid underwent an upfield shift from 179.30 to $175.70 \mathrm{ppm}$ in the pyridinocholaphane 3 due to the formation of the amide bond. The other overlapped carbonyl carbon signals at 8166.80 and 163.47 were attributed to C-29, C-35 and C-27, C-37 carbons, respectively. The aromatic region in ${ }^{13} \mathrm{C}$ was well resolved depicting the carbon signals for C-31, C-32 at 154.15 and C-34 at $138.59 \mathrm{ppm}$. The two quaternary carbons, C-30 and C-33, appeared at $125.40 \mathrm{ppm}$, which 


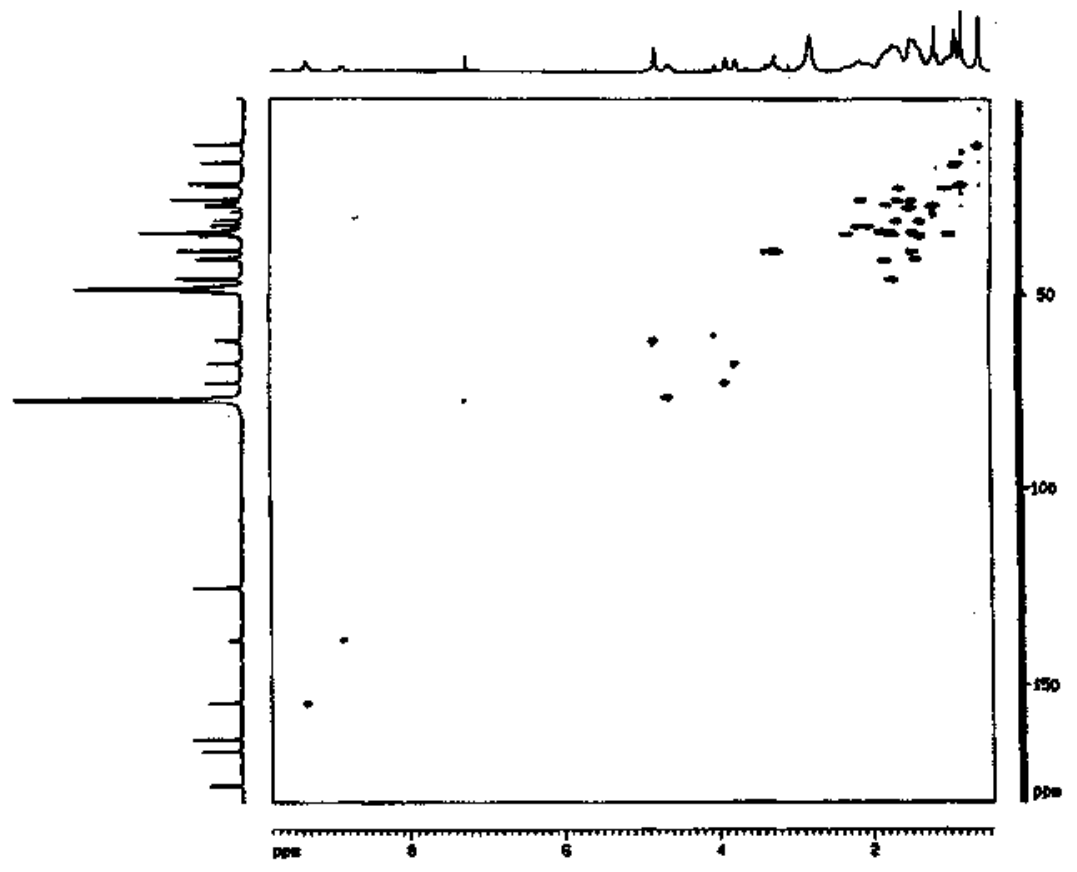

Figure 2. HSQCf'H-^CJ-NMR spectrum of pyridinocholaphane 3.

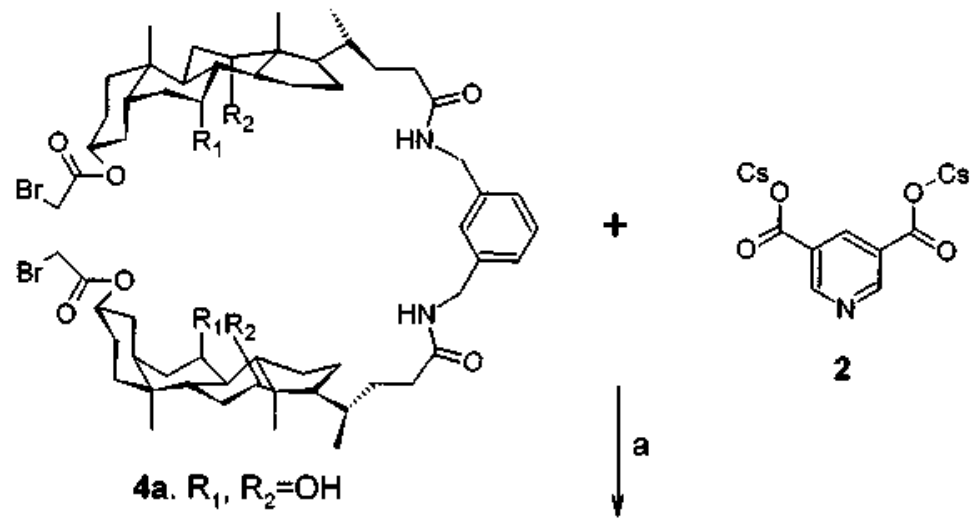

4b. $\mathrm{R}_{1}=\mathrm{H}, \mathrm{R}_{2}=\mathrm{OH}$

4c. $R_{1}, R_{2}=H$

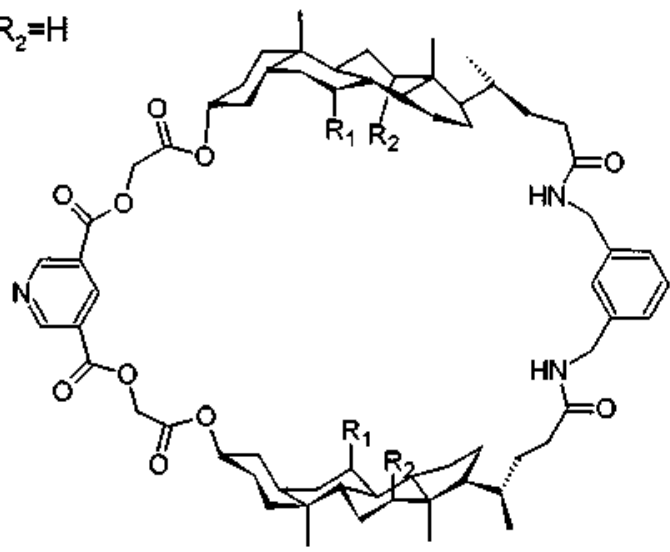

5a. $\mathrm{R}_{1}, \mathrm{R}_{2}=\mathrm{OH}$

5b. $\mathrm{R}_{1}=\mathrm{H}_{1} \mathrm{R}_{2}=\mathrm{OH}$

5c. $R_{1}=R_{2}=H$

Scheme 2. (a) DMF, 12 h, it, (5a) 85\%, (5b) $81 \%$, (5c) $78 \%$. 

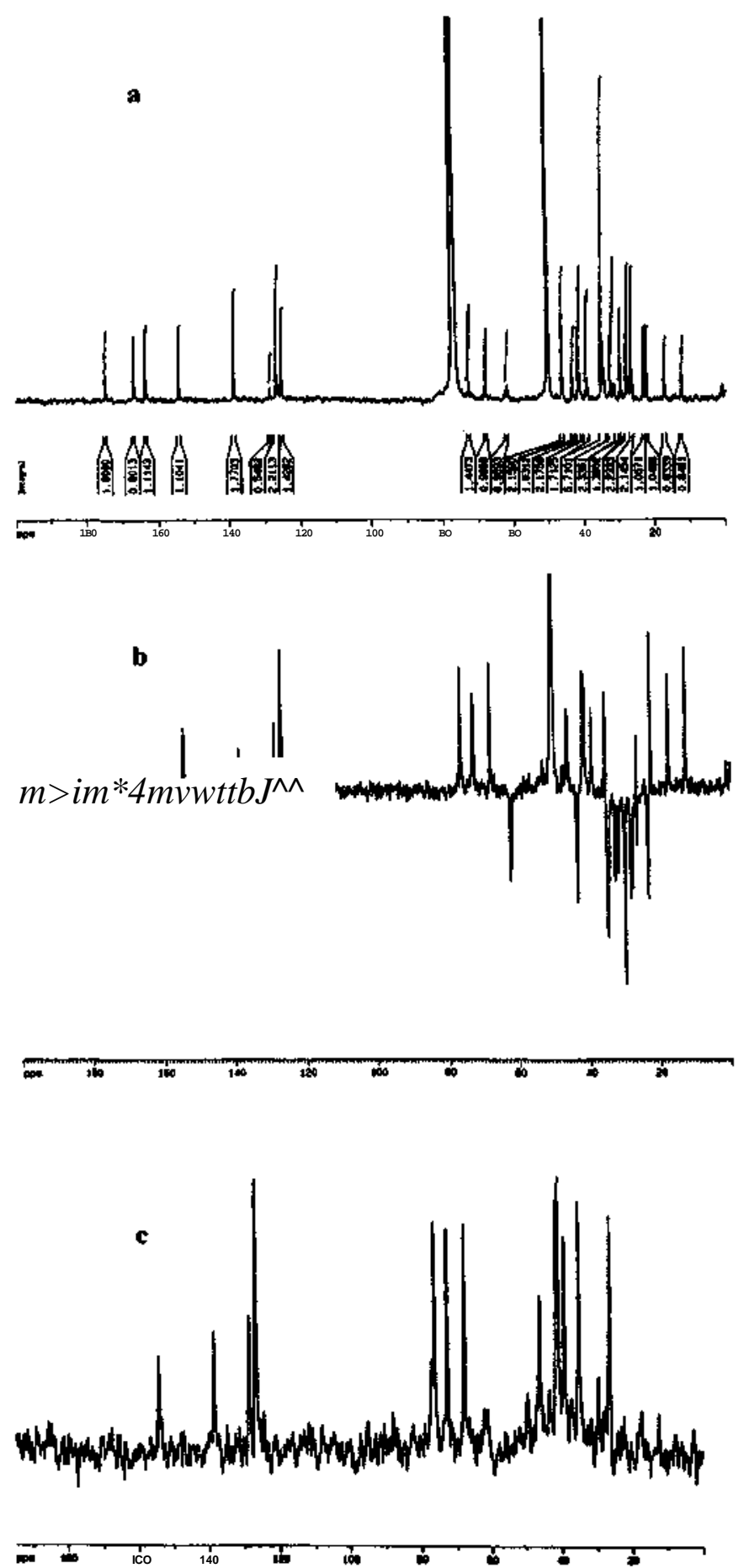

Figure 3. (a) ${ }^{13} \mathrm{C}$ spectrum, (b) $\mathrm{DEPT}{ }^{1 \hat{}} \mathrm{C}\left\{{ }^{\prime} \mathrm{H}\right\} 13 \mathrm{~S}$ - and (c) $\mathrm{DEPT}^{\wedge} \mathrm{Cf}^{\prime} \mathrm{H}^{\wedge} \mathrm{O}-\mathrm{NMR}$ spectrum of pyridinocholaphane 5 a.

was confirmed by their disappearance in $\operatorname{DEPT}^{13} \mathrm{C}\left\{{ }^{\prime} \mathrm{H}\right\} 135-$ NMR spectrum (Fig. lb). Similarly the other steroidal quaternary carbons, $\mathrm{C}-10$ and $\mathrm{C}-13$, were found to resonate at 834.51 and 46.10, respectively.

The ${ }^{13} \mathrm{C}$ NMR spectrum of pyridinocholaphane indicated two carbons less than required. This ambiguity was solved by $\mathrm{DEPT}^{\wedge} \mathrm{C}^{\wedge} \mathrm{HJW}-\mathrm{NMR}$ spectrometry (Fig. 1c), which showed a signal at 876.57 , overlapped with $\mathrm{CDC1}_{3}$ carbon signal in ${ }^{13} \mathrm{C}$ NMR spectrum. This was further supported by $\{$ 'H-^CJHSQC-NMR spectrum of 3 (Fig. 2), revealing a cross peak at 76.57/4.61 ppm, which was assigned to overlapped methine carbons, C-3 and C-3'. It is noteworthy to observe a downfield shift in case of this methine C-3 carbon, which in case of cholic acid and cyclocholates was found to appear at 71.6 and $73.5 \mathrm{ppm}$, respectively, this probably be due to the presence of an extra ester group in case of pyridinocholaphane. The HSQC spectrum further revealed the cross peaks of methylene carbons $-\mathrm{NH}-\mathrm{CH}_{2}-\mathrm{CH}_{2}$ $\mathrm{NH}-$ and $-\mathrm{O}-\mathrm{CH}_{2}-\mathrm{CO}-$ at 39.16/3.27 and 61.62/ $4.81 \mathrm{ppm}$, respectively. The cross peaks confirmed the signals for other methine carbons C-7 and C-12 at 67.71/ 


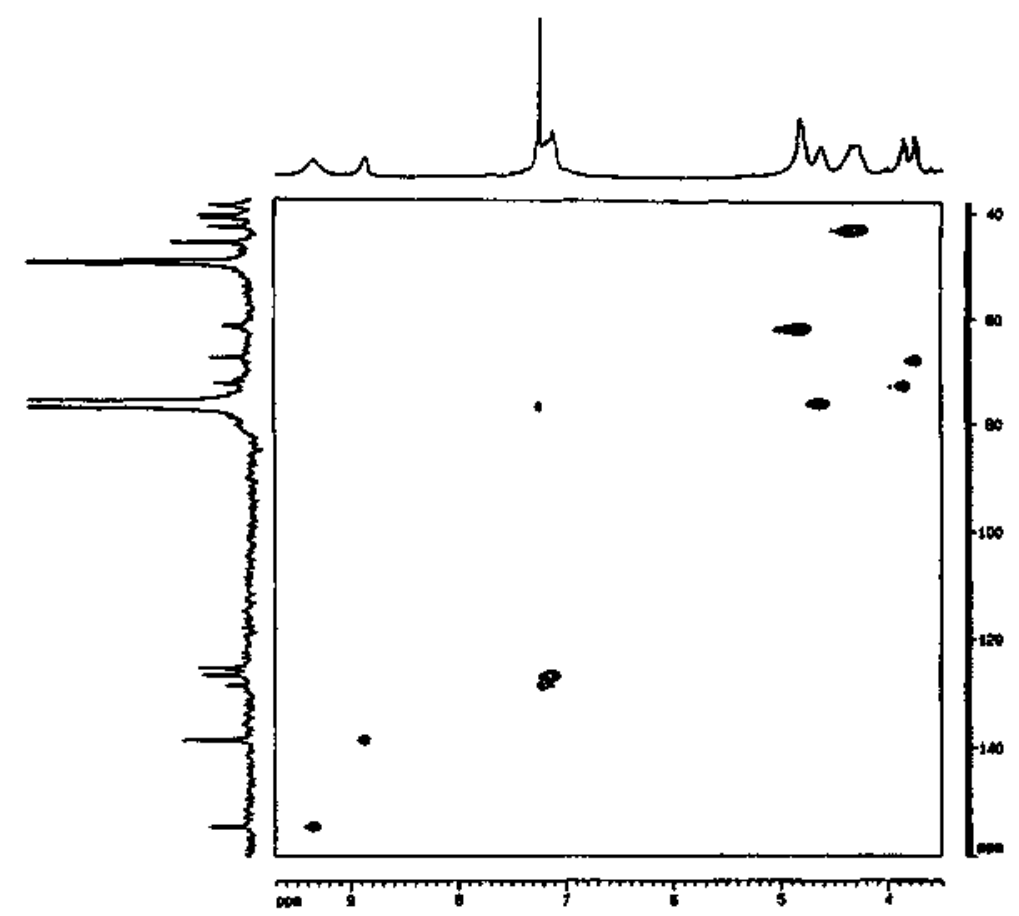

Figure 4. $\mathrm{HSQCf} \mathrm{H}^{\prime} \mathrm{-} \mathrm{CJ}^{-\mathrm{NMR}}$ spectrum of pyridinocholaphane $5 \mathrm{a}$.

3.75 and 72.59/3.88 ppm, respectively. The chemical shifts of the skeletal carbons were assigned on the basis of the literature data. ${ }^{11}$

For the synthesis of pyridinocholaphanes 5a-c, with $\mathrm{m}$-xylylenediamine as spacer, the bis-cholic-m-xylylenediamides were prepared by the method of Burrows and coworkers. $^{12}$ The selective bromoacetylation of these cholamides and cyclization of the resulting products (Scheme 2) was carried out by following the same procedure as described earlier. The $* \mathrm{H}$ NMR spectrum of the obtained pyridinocholaphane $5 \mathrm{a}$ depicted the pyridine protons at 88.92 and 9.39 , and phenyl protons as a multiplet at $7.20 \mathrm{ppm}$. The $-\mathrm{CH}_{2}-\mathrm{Ph}-\mathrm{CH}_{2}-$ protons appeared downfield in this case as a multiplet at 84.37 . The $-\mathrm{CO}-\mathrm{CH}_{2}$ $\mathrm{O}$ - protons were observed as a broad singlet at $4.88 \mathrm{ppm}$. The rest of the steroidal protons appeared at almost the same positions as in the case of pyridinocholaphane 3 . The appearance of molecular ion peak $\left(\mathrm{MH}^{+}\right)$at $\mathrm{mlz} 1165$ in the $\mathrm{FAB}$ mass spectrum indicated the formation of pyridinocholaphane 5a. The quantitative ${ }^{13} \mathrm{C}$ NMR spectrum (Fig. 3a) also supported the structure of pyridinocholaphane $5 \mathrm{a}$. On changing the spacer from ethylenediamine to m-xylylenediamine, the carbonyl carbon C-24 shifted upfield from 175.70 to $174.67 \mathrm{ppm}$. The other two sets of carbonyl carbons appeared at 166.86 and 163.64 ppm showing a minor chemical shift as compared to that of pyridinocholaphane 3. The quantitative 13C NMR spectrum of 5a revealed an overlapped signal for two phenyl quaternary carbons (C-26, C-30) with one pyridine carbon (C-40) at $138.67 \mathrm{ppm}$. These two quaternary carbon signals were confirmed by its disappearance in DEPT ${ }^{\wedge} \mathrm{C}^{\wedge} \mathrm{HJBS}-\mathrm{NMR}$ spectrum (Fig. 3b). The other phenyl carbons (C-27, C-28, $\mathrm{C}-29)$ and C-31 were found to resonate at 126.78 and $128.65 \mathrm{ppm}$, respectively. This was supported by the appearance of the cross peaks at $8126.78 / 7.12$ and
$128.65 / 7.18 \mathrm{ppm}$ in $\mathrm{HSQC}^{\wedge} \mathrm{H}-{ }^{\wedge} \mathrm{CJ}-\mathrm{NMR}$ spectrum (Fig. 4). Furthermore, the cross peaks at $843.20 / 4.37$ and $61.81 / 4.88$ revealed the methylene carbons $-\mathrm{CH}_{2}-\mathrm{Ph}-\mathrm{CH}_{2}$ and $-\mathrm{CO}-\mathrm{CH}_{2}-\mathrm{O}-\mathrm{CO}-$, respectively. The rest of the carbon signals appeared at almost the same chemical shifts as in the pyridinocholaphane 3 . Two more pyridinocholaphanes based on deoxycholic acid 5b, and lithocholic acid $5 \mathrm{c}$, utilizing $\mathrm{m}$-xylylenediamine as a spacer have been synthesized. These pyridinocholaphanes were also characterized on a similar basis and their detailed assignments are given in Table 1.

\section{Conclusion}

Though the FAB mass spectra of pyridinocholaphanes correctly depicted the molecular ion peaks at their respective $\mathrm{mlz}$ values, the combination of NMR techniques, viz. ${ }^{13} \mathrm{C}$ quantitative, $\mathrm{DEPT}^{13} \mathrm{C}\left\{\wedge^{\wedge} 135 / 90\right.$ and $\mathrm{HSQC}^{\wedge} \mathrm{H}-\wedge \mathrm{CJ}-\mathrm{NMR}$, proved to be an effective tool in elucidating the complex structure of pyridinocholaphanes. These pyridinocholaphanes can easily be converted into the dihydropyridine systems by standard methods, JV-alkylation followed by reduction with sodium dithionite. The structural features of these macrocyclic steroidal dihydropyridine systems are expected to selectively bind carbohydrate based substrates and may carry out their reduction in a stereoselective manner.

\section{Experimental}

\subsection{General}

Melting points were not corrected. IR spectra were recorded on Nicolet protégé 460 spectrometer, using potassium 
bromide pellet. ${ }^{1} \mathrm{H},{ }^{13} \mathrm{C}, \quad \mathrm{DEPT}^{13} \mathrm{C}\left\{{ }^{\mathrm{X}_{\mathrm{H}}}\right\} 135 / 90$ and $\mathrm{HSQC}^{\wedge} \mathrm{H}^{\wedge}{ }^{\wedge} \mathrm{CJ}-\mathrm{NMR}$ spectra were recorded on SPECTROSPIN DPX 300 BRUKER. The chemical shifts (8) are given relative to TMS as an internal standard. Mass spectra were obtained using a JEOL SX 102/DA-6000 Mass Spectrometer using Argon/Xenon as the FAB gas and m-nitrobenzyl alcohol as the matrix. Column chromatography was carried out using Qualigens silica gel 60-120 mesh.

4.1.1. Bis-cesium 3,5-pyridine dicarboxylate 2 . To a solution of pyridine-3,5-dicarboxylic acid $(1.67 \mathrm{~g}$, $10 \mathrm{mmol})$ in DMF, cesium carbonate $(3.25 \mathrm{~g}, 10 \mathrm{mmol})$ was added. After complete neutralization, the solvent was evaporated under reduced pressure, white solid of cesium salt was obtained and was dried in desiccator. Yield: $4.6 \mathrm{~g}$, 92\%; IR (KBr): $1600 \mathrm{~cm}^{11}$; ${ }^{l} H$ NMR $\left(\mathrm{DMSO}_{6}\right)$ 8: 8.64 (bs, 1H, Pyr-4-H), 9.24 (bs, 2H, Pyr2, 6-H).

\subsubsection{Cyclo-bis-(3a-acetylcholic)-ethylenediamido-3,5-} pyridine dicarboxylate 3. Bis-(3a-bromoacetylcholic)ethylenediamide 1 (206 mg, $0.19 \mathrm{mmol}$ ) was dissolved in dry dimethyl formamide $(6 \mathrm{ml})$ and to this was added an equivalent amount of bis-cesium 3,5-pyridine dicarboxylate $(86.2 \mathrm{mg}, 0.20 \mathrm{mmol})$. The reaction mixture was stirred at room temperature for $12 \mathrm{~h}$. The mixture was then filtered and the filtrate was poured on ice cold brine solution $(20 \mathrm{ml})$. The solid obtained was filtered and vacuum dried. The compound was purified by column chromatography on silica gel (5\% methanol/95\% chloroform), to afford the product 3 as a white crystalline solid (180 $\mathrm{mg}, 87 \%)$. $R f$. 0.52 (10\% methanol $/ 90 \%$ chloroform). Mp: $240^{\circ} \mathrm{C}$ (decom); IR (KBr): 3418, 1739, $1652 \mathrm{~cm}^{11}$; 'H NMR (CDCI3-CD3OD, $300 \mathrm{MHz})$ 8: 0.60 (s, 6H, 2x18-Me), 0.84 (s, 6H, 2X19-Me), 0.93 (bs, 6H, 2X21-Me), 0.99$2.50\left(48 \mathrm{H}\right.$, Steroidal H), $3.27\left(\mathrm{~m}, 4 \mathrm{H}, 2 \mathrm{xCH}_{2} \mathrm{NHCO}\right)$, 3.75 (bs, 2H, 2X7(3-H), 3.88 (bs, 2H, 2X12(3-H), 4.61 (m, $2 \mathrm{H}, 2 \mathrm{X} 3(3-\mathrm{H}), 4.81$ (bs, 4H, 2xCOCH$\left.{ }_{2} \mathrm{O}\right), 8.85$ (bs, $1 \mathrm{H}$, $\left.\mathrm{Py}_{\mathrm{r}}-4-\mathrm{H}\right), 9.34$ (bs, 2H, Pyr-2, 6-H); ${ }^{13} \mathrm{C}$ NMR $\left(\mathrm{CDC}_{3^{-}}\right.$ CD3OD, $75 \mathrm{MHz}$ ), see Table 1; FAB MS Calcd for $\mathrm{C}_{61} \mathrm{H}_{89} \mathrm{O}_{14} \mathrm{~N} 31089.39(\mathrm{MH})$, Found $1089\left(\mathrm{MH}^{+}\right)(47 \%)$, 1027 (7\%), 949 (8\%), $917(5 \%), 888$ (7\%), $863(5 \%), 828$ (4\%), $705(5 \%), 661(20 \%), 603(6 \%), 535(6 \%), 461$ (10\%), 413 (18\%), 391 (40\%), 341 (12\%), 327 (25\%), 281 (40\%), 267 (22\%), 221 (20\%), 207 (47\%), 176 (34\%), 120 (40\%), 107 (58\%). Anal. Calcd for $\mathrm{C}_{61} \mathrm{H}_{89} \mathrm{O}_{14} \mathrm{~N} 34 \mathrm{H}_{2} \mathrm{O}$ : C, 63.14; H, 8.42; N, 3.62. Found: C, 62.88; H, 8.35; N, 3.51 .

4.1.3. Cyclo-bis-(3a-acetylcholic)-/ra-xylylenenediamido3,5-pyridine dicarboxylate 5a. Bis-(3a-bromoacetylcholic)-m-xylylenediamide $\mathbf{4 a}$, (232 $\mathrm{mg}, 0.20 \mathrm{mmol})$ was dissolved in DMF $(8 \mathrm{ml})$ and treated with an equivalent amount of bis-cesium 3,5-pyridine dicarboxylate $(90.5 \mathrm{mg}$, $0.21 \mathrm{mmol}$ ) at room temperature for $12 \mathrm{~h}$. The product after work up was purified by column chromatography on silica gel (5\% methanol/95\% chloroform), to give the product 5a as a white crystalline solid (198 mg, 85\%). Rf. $0.56(10 \%$ methanol/90\% chloroform). Mp: $170-172^{\circ} \mathrm{C}$; IR (KBr): $3419, \quad 1736,1653 \mathrm{~cm}^{11}$; 'H NMR $\left(\mathrm{CDC1}_{3}-\mathrm{CD}_{3} \mathrm{OD}\right.$, $300 \mathrm{MHz}$ ) 8: 0.66 (bs, 6H, 2xl8-Me), 0.90 (s, 2H, 2x19Me), 0.97 (bs, 6H, 2X21-Me), 1.00-2.40 (48H, Steroidal H),
3.81 (bs, 2H, 2X7(3-H), 3.91 (bs, 2H, 2X12(3-H), 4.37 (m, $\left.4 \mathrm{H}, 2 \mathrm{xPhCH}_{2} \mathrm{NH}\right), 4.69(\mathrm{~m}, 2 \mathrm{H}, 2 \mathrm{X} 3(3-\mathrm{H}), 4.89(\mathrm{~m}, 4 \mathrm{H}$, 2XCOCH $\mathrm{XCH}_{2} \mathrm{O}, 7.20$ (m, 4H, Ar-H), 8.92 (bs, 1H, Pyr-4-H), 9.40 (bs, 2H, Pyr-2, 6-H); ${ }^{13} \mathrm{C}$ NMR (CDCI3-CH3OD, $75 \mathrm{MHz}$ ), see Table 1; FAB MS Calcd for $\mathrm{QVH}^{\wedge} \mathrm{OMN}$, $1187.48(\mathrm{MNa}), 1165.49(\mathrm{MH})$, Found $1187\left(\mathrm{MNa}^{+}\right)$ (6\%), $1165\left(\mathrm{MH}^{+}\right)(40 \%), 1147(7 \%), 1089(8 \%), 810$ $(5 \%), 675(5 \%), 661(28 \%), 460(5 \%), 391(34 \%), 257$ (5\%), $207(13 \%), 176(14 \%), 120(18 \%)$. Anal. Calcd for $\mathrm{C}_{67} \mathrm{H}_{9} 3 \mathrm{~N} 3 \mathrm{O}_{14} 4 \mathrm{H}_{2} \mathrm{O}: \mathrm{C}, 65.07 ; \mathrm{H}, 8.23 ; \mathrm{N}, 3.39$. Found: $\mathrm{C}$, 64.75; H, 8.13; N, 3.29.

4.1.4. Cyclo-bis-(3a-acetyldeoxycholic)-/ra-xylylenediamido-3,5-pyridine dicarboxylate $5 \mathrm{~b}$. Bis-(3a-bromoacetyldeoxycholic-m-xylylenediamide 4b (248 mg, $0.22 \mathrm{mmol}$ ) was dissolved in DMF $(7 \mathrm{ml})$ and bis-cesium 3,5-pyridine dicarboxylate $(100 \mathrm{mg}, 0.23 \mathrm{mmol})$ was added. The mixture was stirred at room temperature for $12 \mathrm{~h}$. The work up procedure followed was same as described earlier. The crude product was subjected to column chromatography (4\% methanol $/ 96 \%$ chloroform), to give the product $\mathbf{5 b}$ as a white crystalline solid (202 mg, 81\%). Rf. $0.61(10 \%$ methanol/90\% chloroform). Mp: $215^{\circ} \mathrm{C}$ (decom); IR (KBr): 3410, 1739, $1655 \mathrm{~cm}^{11} ;{ }^{l} H$ NMR $\left(\mathrm{CDCl}_{3}-\mathrm{CD}_{3} \mathrm{OD}\right.$, $300 \mathrm{MHz})$ 8: 0.66 (s, 6H, 2x18-Me), 0.91 (s, 6H, 2x19$\mathrm{Me}$ ), 1.02 (bs, 6H, 2X21-Me), 1.05-2.50 (52H, Steroidal $\mathrm{H}), 3.95$ (bs, $2 \mathrm{H}, 2 \mathrm{Xl} 2(3-\mathrm{H}), 4.36\left(\mathrm{~m}, 4 \mathrm{H}, 2 \mathrm{XhCH}_{2} \mathrm{NH}\right)$, $4.88\left(\mathrm{~m}, 6 \mathrm{H}, 2 \mathrm{xCOCH}_{2} \mathrm{O}\right.$ and $2 \mathrm{X} 3(3-\mathrm{H}), 7.20(\mathrm{~m}, 4 \mathrm{H}, \mathrm{Ar}-\mathrm{H})$, 8.95 (s, 1H, Pyr-4-H), 9.46 (s, 2H, Pyr-2, 6-H). ${ }^{13} \mathrm{C}$ NMR (CDCI3-CD3OD, $75 \mathrm{MHz}$ ), see Table 1; FAB MS Calcd for $\mathrm{C}_{67} \mathrm{H}_{93} \mathrm{O}_{12} \mathrm{~N} 31133.49(\mathrm{MH})$, Found $1133\left(\mathrm{MH}^{+}\right)$ (92\%), 1097 (25\%), 1011 (11\%), $953(6 \%), 872(20 \%)$, $759(12 \%), 732(8 \%), 693(8 \%), 654(10 \%), 622(32 \%)$, $600(37 \%), 582$ (12\%), 536 (12\%), $512(12 \%), 489(10 \%)$, 474 (24\%), 438 (42\%), 377 (15\%), 339 (40\%), 255 (90\%), $241(45 \%), 225(100 \%), 199(55 \%), 176(71 \%), 131$ $(100 \%), 107(100 \%)$. Anal. Calcd for $\mathrm{C}_{67} \mathrm{H}_{9} 3 \mathrm{~N}_{3} \mathrm{O}_{12}-2 \mathrm{H}_{2} \mathrm{O}$ : C, 68.86; H, 8.36; N, 3.60. Found: C, 68.38; H, 8.22; N, 3.65 .

4.1.5. Cyclo-bis-(3a-acetyllithocholic)-/ra-xylylenediamido-3,5-pyridine dicarboxylate 5c. Bis-(3a-bromoacetyllithocholic)-m-xylylenediamide $\quad 4 c \quad$ (460 mg, $0.42 \mathrm{mmol}$ ) and bis-cesium 3,5-pyridine dicarboxylate (185.3 mg, $0.43 \mathrm{mmol}$ ) were dissolved in DMF $(15 \mathrm{ml})$ and the solution was stirred at room temperature for $12 \mathrm{~h}$. The usual work up gave the compound which was purified by column chromatography on silica gel (2\% metanol/98\% chloroform) to give the product $\mathbf{5 c}$ as a white crystalline solid (361 mg, 78\%). Rf. 0.55 (8\% methanol/92\% chloroform). Mp: $179-180^{\circ} \mathrm{C}$; IR (KBr): $3300,1735,1652 \mathrm{~cm}^{\prime 1}$; 'H NMR (CDCI3, $300 \mathrm{MHz})$ 8: 0.57 (bs, 6H, 2X18-Me), 0.85 (bs, 12H, 2X19-Me and 2X21-Me), 1.07-2.50 $(56 \mathrm{H}$, Steroidal H), $4.32\left(\mathrm{~m}, 4 \mathrm{H}, 2 \mathrm{xPhCH}_{2} \mathrm{NH}\right), 4.80(\mathrm{~m}, 6 \mathrm{H}$, $2 \mathrm{XCOCH}_{2} \mathrm{O}$ and $2 \mathrm{X} 3(3-\mathrm{H}), 7.12$ (bs, 4H, Ar-H), 8.91 (bs, 1H, Pyr-4-H), 9.38 (bs, 2H, Pyr-2, 6-H); ${ }^{13} \mathrm{C} \mathrm{NMR}\left(\mathrm{CDC}_{3}\right.$, $75 \mathrm{MHz}$ ), see Table 1; FAB MS Calcd for $\mathrm{QyH}^{\wedge} \mathrm{OioN}$, $1101.49(\mathrm{MH})$, Found $1101\left(\mathrm{MH}^{+}\right)(23 \%), 1045(6 \%)$, $820(4 \%), 743(5 \%), 661(6 \%), 611(5 \%), 477(10 \%), 440$ $(12 \%), 413(8 \%), 371(24 \%), 341(7 \%), 329(20 \%), 255$ (13\%), 225 (15\%), 201 (10\%), 176 (62\%), 119 (45\%), 105 (85\%). Anal. Calcd for $\mathrm{CgyH}^{\wedge} \mathrm{NAo}: \mathrm{C}, 73.13 ; \mathrm{H}, 8.51 ; \mathrm{N}$, 3.81; Found: C, 73.29; H, 8.73; N, 3.98. 


\section{Acknowledgements}

We thank the All India Council for Technical Education for financial support and the Central Drug Research Institute, Lucknow for recording the FAB mass spectra.

\section{References}

1. (a) Burgess, V. A.; Davies, S. G.; Skerlj, R. T. Tetrahedron: Asymmetry 1991, 2, 299-328. (b) Murakami, Y.; Kikuchi, J.; Hisaeda, Y.; Hayashida, O. Chem. Rev. 1996, 96, 721-758.

2. (a) Toyooka, Y.; Matsuzawa, T.; Eguchi, T.; Kakinuma, K. Tetrahedron 1995, 51, 6459-6474. (b) Obika, S.; Nishiyama, T.; Tatematsu, S.; Miyashita, K.; Iwata, C; Imanishi, T. Tetrahedron 1997, 53, 593-602. (c) Mikata, Y.; Hayashi, K.; Mizukami, K.; Matsumoto, S.; Yano, S.; Yamazaki, N.; Ohno, A. Tetrahedron Lett. 2000, 41, 1035-1038. (d) Gran, U.; Wennerstrom, O.; Westman, G. Tetrahedron: Asymmetry 2000, 11, 3027-3040.

3. Murakami, Y.; Aoyama, Y.; Kikuchi, J. J. Chem. Soc, Perkin Trans. 1 1981, 2809-2815.

4. Yoon, C. J.; Ikeda, H.; Kojin, R.; Ikeda, T.; Toda, F. j. Chem. Soc, Chem. Commun. 1986, 1080-1081.

5. Behr, J. P.; Lehn, J. M. J. Chem. Soc, Chem. Commun. 1978, 143-146.
6. (a) De Vries, J. G.; Kellogg, R. M. J. Am. Chem. Soc 1979, 101, 2759-2761. (b) Jouin, P.; Trootswijk, C. B.; Kellogg, R. M. J. Am. Chem. Soc 1981, 103, 2091-2093.

7. (a) Davis, A. P. Chem. Soc Rev. 1993, 22, 243-254. (b) Li, Y. X.; Dias, J. R. Chem. Rev. 1997, 97, 283-304. (c) Walliman, P.; Marti, T.; Furer, A.; Diederich, F. Chem. Rev. 1997, 97, 1567-1608.

8. (a) Bonar-Law, R. P.; Davis, A. P. J. Chem. Soc, Chem. Commun. 1989, 1050-1052. (b) Bonar-Law, R. P.; Davis, A. P. Tetrahedron 1993, 49, 9829-9844. (c) Bonar-Law, R. P.; Davis, A. P.; Dorgan, B. J. Tetrahedron 1993, 49, 9855-9866. (d) Bonar-Law, R. P.; Sanders, J. K. M. J. Am. Chem. Soc. 1995, 117, 259-271.

9. (a) Bhattarai, K. M.; Bonar-law, R. P.; Davis, A. P.; Murray, B. A. J. Chem. Soc, Chem. Commun. 1992, 752-754. (b) Bonar-Law, R. P.; Davis, A. P.; Murray, B. A. Angew. Chem., Int. Ed. Engl. 1990, 29, 1407-1408.

10. Pandey, P. S.; Singh, R. B. Tetrahedron Lett. 1997, 38, 5045 5046.

11. (a) Bonar-Law, R. P.; Davis, A. P. Tetrahedron 1993, 49, 9845-9854. (b) Dias, J. R.; Gao, H.; Kolehmainen, E. Spectrochimica. Ada, Part A 2000, 56, 53-77.

12. (a) Burrows, C. J.; Sauter, R. A. J. Inclusion Phenom. 1987, 5, 117-121. (b) Kinneary, J. F.; Roy, T. M.; Albert, J. S.; Yoon, H.; Wagler, T. R.; Shen, L.; Burrows, C. J. J. Inclusion Phenom. Mol. Recognit. Chem. 1989, 7, 155-168. 